\title{
Spanglish in Advertising
}

\author{
ANDREW SMITH \\ Escuela de Literatura y Ciencias del Lenguaje \\ Universidad Nacional, Costa Rica \\ Escuela de Lenguas Modernas \\ Universidad de Costa Rica
}

\begin{abstract}
This paper will study some historical issues in the development of advertising and Spanglish, how they came to be related and how they are articulated. The significance of this research lies in the fact that although Spanglish is now a common occurrence in Latin American Spanish, especially in advertising, the dynamics of these two fields has rarely been analyzed. Thus, this study can give us important insights into the everchanging Spanish language, the role that English plays in these changes, and how advertising capitalizes on language for commercial profit.
\end{abstract}

Key words: Spanglish, advertising, language as a marketing strategy, the use of English in marketing, linguistic strategies of marketing

\section{Resumen}

Este artículo estudia algunos acontecimientos históricos en el desarrollo de la publicidad y del Spanglish y cómo estos dos campos se relacionan. La importancia de esta investigación radica en el hecho que aunque el Spanglish es ahora común en el español de Latinoamérica, especialmente en la publicidad, la dinámica de estos dos temas ha sido raramente analizada. Por lo tanto, este estudio nos da una amplia perspectiva de la cambiante lengua española, del papel que el inglés juega en estos cambios, y de cómo la publicidad capitaliza la lengua para lograr ganancias comerciales.

Palabras claves: Spanglish, publicidad, la lengua como estrategia de mercado, uso del inglés en el lenguaje publicitario, estrategias lingüísticas de mercadeo 
A dvertising seems to be, in theory, a very easy field to define. Its definition from any dictionary is basically the action of attracting clients to a product or to a business in order to sell something. However, a closer study of the field of advertising shows that it is not quite that simple. A statement such as "Advertising is show business" (Tungate, 11) or advertising is "the official art of capitalism" (Harvey, 63) are insights into the complexity of this seemingly "simple field," which as we shall see, is much more than mere sales. Adorno and Horkheimer, for example, state that advertising controls society, it controls the consumer, and it even shapes language. In fact, advertising shows how social power is represented; it is the "elixir of life" of the culture industry (Adorno and Horkheimer, 22-23).

Spanglish, also known as "espanglish" or "engliñol" (Lipski, 1) and even englañol (Ardila, 63) in the Unites States, has even more names in Mexico, where it may be known as "espanglés", "casteyanqui”, "inglañol”, "argot sajón”, "español bastardo", "papiamento gringo", or "caló pachuco" (Stavans, 2000, 555). Like advertising, the concept of Spanglish is not as easily defined as one might think. Every English speaking student of Spanish and every Spanish speaking student of English knows that Spanglish is a mixture of Spanish and English. But beyond that, many questions can be raised as to exactly how Spanish and English are combined. Just as there are many different names for Spanglish, there are also many definitions. John M. Lipski, in his article "Is 'Spanglish' the third language of the South? : truth and fantasy about US Spanish," lists twenty eight different "definitions" of Spanglish from different authors and sources. In addition, questions such as the following show the complexity of the term: "Who uses spanglish and in what circumstances? [...] When and where is spanglish used and not used? [...] How is spanglish acquired? [...] Can spanglish be characterized technically as a jargon, a pidgin, or a creole language? [...] Does spanglish have native speakers? [...] Does spanglish have a common linguistic core, understood and used by all speakers/listeners? [...] Do regional or social dialects of spanglish exist?" (Lipski, 1-3).

Vanessa Parra also reinforces this complexity when she states: "Spanglish is a language, lifestyle, and culture that has one foot in each set of traditions. It is a mix of Spanish and English language that is informal and focuses on trends in fashion, music, news, and art that appeals to a person who enjoys aspects of the American and Latino culture. This new culture voices opinions and values that might not be seen as acceptable by Americans or Latinos" (Parra, 4-5).

Historically, sometime and somehow, advertising and Spanglish came into contact. This study will briefly present the history of advertising and the history of Spanglish and will then show how these two fields came together.

Advertising, like Spanglish, can be controversial. Many people consider advertising to be "sheer manipulation" and a form of control, having a strong effect on our lives (Tungate, 3). In their article, "The Culture Industry: Enlightenment as Mass Deception" Adorno and Horkheimer speak of the customer in culture, and how the 
customer is manipulated and even "overpowered" by culture, which is exactly what advertising achieves to do, that is, convince someone to buy something. Again, the concept of Spanglish can also be visualized in the following assertion:

By the language [the customer] speaks, he makes his own contribution to culture as publicity. The more completely language is lost in the announcement, the more words are debased as substantial vehicles of meaning and become signs devoid of quality; the more purely and transparently words communicate what is intended, the more impenetrable they become. [...] But the result is that the word, which can now be only a sign without any meaning, becomes so fixed to the thing that it is just a petrified formula (Adorno \& Horkheimer, 23).

The customer, who can here be represented by the speaker of Spanglish, does make his or her contribution to culture, though not necessarily through publicity, but simply by interacting in the culture through language. However, when Spanglish is literally seen in advertising, it is not always for communication reasons but rather only for effect. An example is the television commercial for the online English course "Open English," where the pretty blond stewardess asks the Latino if he is "...comfortable sitting in the exit row" and he answers with two thumbs up "Éxito!" There is no communication here, only effect. As Adorno and Horkheimer state before, the words "are debased as substantial vehicles of meaning and become signs devoid of quality." Thus, miscommunication becomes a spectacle, one that is used to sell a product.
Gloria Anzaldúa, in her book Borderlands/La Frontera also asserts that culture has an economic effect on speakers of Spanglish as well as other "nonstandard" people:

This voluntary (yet forced) alienation makes for psychological conflict, a kind of dual identity - we don't identify with the Anglo-American cultural values and we don't totally identify with the Mexican cultural values. We are a synergy of two cultures with various degrees of Mexicanness or Angloness. I have so internalized the borderland conflict that sometimes I feel like one cancel out the other and we are zero, nothing, no one. A veces no soy nada ni nadie. Pero hasta cuando no lo soy, lo soy (85).

Herbert Marcuse also speaks of culture as an hegemonic, authoritarian discourse that controlls language and people:

However, the authoritarian ritualization of discourse is more striking where it affects the dialectical language itself. The requirements of competitive industrialization and the total subjection of man to the productive apparatus appears in the authoritarian transformation of the Marxist into the Stalinist and post-Stalinist language. These requirements, as interpreted by the leadership which controls the apparatus, define what is right and wrong, true and false. (80).

This control of language is passed into advertising as the "language of truth" which in turn makes it much easier to sell something.

However, to some advertising is much more than mere control. Working 
in advertising is considered to be trendy and "cool," and an advertising agency seems to be a glamorous place to work (Tungate, 1). Advertising serves the economy by creating demand for a product or for products, stimulating the development of new products and creating competition. It also finances the media, and it is "the accelerator at the heart of a liberal economy" (Tungate, 3). If done well, advertising is practically or even literally an art form. The advertising industry is also a place where writers and film directors can sharpen their skills, while being paid. For example, many film directors and writers had their start in advertising (Tungate, 4). Advertsing historically allowed the manufacturer of a product to gain power or control over how the product was to be sold when dealing with distributors of the product (Norris, 6). Before advertising existed, the manufacturer of a product had little or no power concerning the sale of his product, or even concerning the product that he would manufacture. The distributor would tell the manufacturer what he wanted, and how much he would pay for it. When the manufacturer or maker of the product started giving his product a name, or brand, and began advertising it, he essentially put himself in a position of power over the distributor, for he could tell the distributor how much money he needed to have in order to sell him his product. The manufacturer could set his own price, and then the distributor needed the manufacturer more than the manufacturer needed the distributor. Giving a brand to one's product and advertising it also helped to eliminate competition by convincing consumers that this brand was better than other competing brands (Norris, 6). Without going into all the effects that advertising has had, has, and will continue to have on society, which is not the goal of this study, suffice it to say that advertising has played, does play and will continue to play an extremely important role in our lives.

When did advertising begin? It is safe to say that some form of advertising has existed ever since goods have been exchanged. The Greeks seemed to have advertised with lead sheets (Bulletin of the Business Historical Society, 13) and the Egyptians and Romans had forms of advertising (Tungate, 10). One interesting example is from the ruins of Pompeii, where a sign advertising a brothel was found. This, as Mark Tungate states, is "An appealing idea: the two oldest professions benefiting from each other" (10). Other theories about advertising are interesting yet not easy to prove. One is that the Rosetta Stone was a poster, and the inscriptions on the wall on Hammurabi's temple in Uruk were actually "corporate billboard advertising" (Norris, 4). Some even maintain that prehistoric cave paintings were an early form of advertising (Tungate, p. 10).

The invention of the printing press in 1447 was of course a great help in the growth or development of advertising, for obvious reasons (Tungate, 10). What before had to be written by hand could then be printed in mass. With the passage of time, we find other specific cases of advertising in history. In 1679, Jonathan Holder, a haberdasher in London, gave every customer a printed list of the goods he had in stock, with their corresponding prices. He was criticized for this "unnecessary" expenditure. Another noteworthy case of early advertising is seen with Théophraste Renaudot, a Frenchman who through his friend 
Richelieu, who would eventually be the famous Cardinal Richelieu, became Louis XIII's official doctor. Before this, Renaudot was an advocate of helping poor Parisians. He put up a bulletin board for people looking for jobs, and those offering work and goods. In order to more efficiently spread this information in 1631, Renaudot created the first French newspaper, with the iconic name of "La Gazette." Renaudot is considered to be the first French journalist and the inventor of the personal ad (Tungate, 11) as well.

In the United States, or more correctly in the thirteen British colonies that existed before the United States were independent from Britain, the newspaper The Pennsylvania Evening Post, dated July 6, 1776, just two days after the signing of the Declaration of Independence, printed a copy of the Declaration of Independence, which was certainly important news of the time. The document was followed by several advertisements, one of which was for selling coffee. This ad was taken out by a certain Isaac Hazelhurst, who offered "coffee of the best quality" to the public (Norris, 5).

The first advertising agent in the United Kingdom was probably a man named William Tayler, who opened an office in London in 1786. Tayler worked with printers as an advertising sales representative, and was therefore working with newspapers (Tungate, 11). The first advertising agency in the Unites States was opened by Volney B. Palmer in 1842, in Philadelphia. Like Tayler, Volney worked with newspapers, and not with advertisers. So the first advertising agents or agencies in both the United Kingdom and the United States did not work creat- ing ads, such as an advertising agency does today, but rather in selling spaces for ads. And since they sold space in a newspaper, charging a commission, not only did they not really work in advertisement, but there was also the possibility (probability) of corruption since they could charge whatever amount they wanted. Basically, advertising during this time was not yet a real profession it was only a trade, and a dishonest trade at that, according to Tungate (14). Finally, respectability came to advertising in the newspapers when advertisers were charged a fixed commission, which eliminated the possibility of corruption (Tungate, 15). And the rest is history, so to speak. With the creation of railroads, the radio, cinemas, television, magazines and other inventions, the possibilities for more advertising in innovate ways became almost as varied as they are today.

Just as advertising can be considered controversial in that it may manipulate the public, Spanglish also has its polemic side. Ilan Stavans tells us that "The topic of Spanglish generates enormous controversy. Its army of critics uses an array of arguments against it: that it bastardizes standard English and/or Spanish; it delays the process of assimilation of Hispanics into the melting pot; it is proof of the way the American empire dismantles other competing cultures; it confuses children in the age of language acquisition; and it segregates an ethnic minority already ghettoized by economic factors" (Stavans, 2008, preface). In his book Spañglish: The Making of a New American Language Stavans states:

Spanglish is often described as the trap, la trampa Hispanics fall into on 
the road to assimilation - el obstáculo en el camino. Alas, the growing lower class uses it, thus procrastinating the possibility of un futuro mejor, a better future [...] Asked by a reporter in 1985 for his opinion on el espanglés, Octavio Paz [...] a recipient of the Nobel Prize for Literature, is said to have responded with a paradox: "ni es bueno ni es malo, sino abominable" - it is neither good nor bad but abominable. This wasn't an exceptional view: Paz was one of scores of intellectuals with a distaste for the bastard jargon, which, in his eyes, didn't have gravitas. Una lengua bastarda: illegitimate, even wrongful" (Stavans, 2003, 3-4).

John Lipski notes that the term Spanglish and its "related connotations" serve to "...denigrate the linguistic abilities of Hispanic speakers born or raised in the United States" (1). In the twenty eight definitions of Spanglish that Lipski presents, we find some such as "A type of Spanish contaminated by English words and forms of expression..."; Spanglish "plantea un grave peligro de los hispanos dentro de la corriente mayoritaria norteamericana"; "Speakers of the non-defined mixture of Spanish and/or English are judged as 'different' or 'sloppy' speakers of Spanish and/or English and are often labeled verbally deprived, alingual, or deficient bilinguals because supposedly they do not have the ability to speak either English or Spanish well" (1-3).

Marta Fairclough states that "Los llamados 'puristas' de la lengua insisten en que el Spanglish es una aberración que pone en peligro la cultura hispana y las posibilidades de avance de los hispanos en Estados Unidos"
(188). Alfredo Ardila says that "Spanglish has been related to and often associated with low-educated people and even with the underground world" (65, quoting Pamies-Beltran, 1995). He also affirms that "Spanglish has been interpreted just a deformed and corrupted Spanish" (Ardila, 65, quoting Zentella, 1997). Spanglish is even considered by some to be an "invasion of Spanish by English" (Lipski, 4, quoting Robert González-Echeverría, 1997). For example, Virginia Zúñiga Tristán, in her book El anglicismo en el habla costarricense speaks of the "penetración" of English into the Costa Rican culture (21). Penetration, in this case, can easily symbolize violence, subjugation and rape of the Costa $\mathrm{Ri}$ can Spanish language and of the Costa Rican culture. And Gloria Anzaldúa recounts how she was criticized by her peers when she would speak "English": "Pocho, cultural traitor, you're speaking the oppressor's language by speaking English, you're ruining the Spanish language,'[...] Chicano Spanish is considered by the purist and by most Latinos deficient, a mutilation of Spanish" (Anzaldúa, 77).

In short, the negative interpretation of Spanglish, according to these scholars, can be summarized as follows: Spanglish is deforming or destroying both languages, Spanish and English. Spanglish is also repressing the Hispanic people since it segregates Latinos; and it allows the American culture to destroy other cultures; Spanglish even confuses children who are in the process of language acquisition. These negative judgments of Spanglish lead to the idea that Spanglish, like colonization, is all about control and that the language is being used or is manifest- 
ing itself through the domination of some cultural groups. But, what do the defenders of Spanglish think?

For many scholars, Spanglish is a form of identity, and as a means of communication must fit into our modern times. Whatever our opinion of Spanglish, we cannot ignore its existence, and as such it must be recognized as a part of our modernity, and definitely a part of the communicative side of a language. Marta Fairclough says that Spanglish is more than a linguistic phenomenon, but "una metáfora para una nueva forma de vida, un nuevo espacio cultural, cuyas fronteras parecen no tener límites" (189). Fairclough's definition has even mythical resonance. Interestingly enough, Roland Barthes says, when speaking of the concept of a myth, that "Myth is a type of speech," for "myth is a system of communication, that it is a message [...] it is a mode of signification, a form" (107). Stuart Hall also compares language to a myth. He says that for Althusser, who follows the Saussurean conception of language, "language speaks us, as the myth "speaks" the myth-maker" (101). Taking this last view, the Spanglish speaker would be that myth-maker and by using Spanglish, he/she is forging an identity.

On one hand, Sergio Martínez Luna, reinforcing the binarism between culture and language, mentions "high" culture and culture of the mass or popular culture. He states that culture is no longer only seen in art and education, but in other forms that must be "reinvented" (106). Spanglish is a perfect example of this reinvention and a form of popular culture or culture of the masses. On the other hand, Miriam Cárdenas Torres, in her article
"Migración, ciudadanía y articulación en red. El caso de la SB 1070" citing Rosaldo (1994), proposes "la ciudadanía como cultural se explica como el derecho a ser diferente con respecto a la comunidad nacional dominante, ya sea en raza, religión o lengua nativa" (5). We can ask ourselves if Spanglish could be, to a certain extent, considered a native language. Bettina E. Schmidt not only defends the right to be culturally different but also maintains that people of mixed heritage are no longer considered to be inferior, and being "mixed" is now considered to be a positive attribute, she states that:

El mestizaje se describe en este caso como el resultado positivo del encuentro de diferentes "razas", como esencia de la realidad americana, como expresión única de una síntesis que encuentra su punto culminante en el cristianismo, el idioma castellano y la mirada hacia Europa (14).

This scientific discourse concerning mestizaje or mixing can be applied to Spanglish which is seen in a negative light by many precisely because it mixes the Spanish and English languages. However, for some such as Stavans, Spanglish is the "positive result of the encounter of different languages."

Spanglish is popular language, not necessarily made to be written down, it is above all an oral form, and it is a form of revolt against the society that would try to censure it. In his book One-Dimensional Man: Studies in the Ideology of Advanced Industrial Society, Herbert Marcuse, when talking about discourse in society, states: "Society expresses its requirements directly in the linguistic material but not 
without opposition; the popular language strikes with spiteful and defiant humor at the official and semi-official discourse. Slang and colloquial speech have rarely been so creative (70). Marcuse's vision of discourse in society, concerning slang and colloquial speech can also be applied to Spanglish. It would be an interesting study to try to identify or classify Spanglish words into slang, either Spanish or English slang or colloquial words, but beyond that, Spanglish seems to also do in society what Marcuse says slang does. In other words, Spanglish does "strike with spiteful and defiant humor at the official and semi-official discourse" of society, by defying both Spanish and English when these two languages are mixed. Spanglish is definitely creative, for its speakers revolt against standard Spanish and standard English. In essence, through Spanglish, Spanish and English come together and are related, but in a seemingly uncomfortable way for the people who oppose Spanglish. But isn't this normal? As Jean-François Lyotard declares in The Postmodern Condition: A Report on Knowledge: "Nevertheless, language species, like living species, are interrelated, their relations are far from harmonious" (27).

Ilan Stavans does not see Spanglish as having a negative effect on languages or on cultures, but rather sees it as a dynamic, positive and creative force that should be embraced instead of feared and criticized. In his opinion, the controversy surrounding Spanglish is proof of its very power. It should have a place in the classroom. Already active in the media and in advertising, this author feels that Spanglish should also be used in politics as well (Stavans, 2008, preface).
Gloria Anzaldúa not only defends Spanglish, but considers it to be a native language that developed naturally, in the construction of identity of its speakers:

But Chicano Spanish is a border tongue which developed naturally. Change, evolución, enriquecimiento de palabras nuevas por invención o adopción have created variants of Chicano Spanish, un nuevo lenguaje. Un lenguaje que corresponde a un modo de vivir. Chicano Spanish is not incorrect, it is a living language.

For a people who are neither Spanish nor live in a country in which Spanish is a first language; for a people who live in a country in which English is the reigning tongue but who are not Anglo[...] what recourse is left to them but to create their own language? (77)

Rafael Vidal Jiménez in his article "La historia y la postmodernidad" states that: "Hemos de afrontar la crisis del representacionismo como principio de correspondencia entre lenguaje y realidad impulsada, en parte, por Richard Rorty y su concepto de 'giro lingüístico'. Esto se traduce en una concepción de la realidad como producto cultural, como entidad no-preexistente al proceso social de creación y captación simbólica de la misma" (26). And Stavans, who along with Anzaldúa, is one of the most ardent supporters of Spanglish, tells us that in Latin America, Spanglish is considered by some to be a "revenge" against the imperialistic language that was forced upon the indigenous people by the colonizers. Scholars, as we have seen, may criticize Spanglish, Stavans affirms, but the general population sees it as a way to get back at the language 
of colonization, in this case Spanish, by having their "own" language, so to speak (Stavans, 2012, 151-152).

Michel Foucault seems to support Anzaldúa's idea that a language is natural and spoken spontaneously. He says, "language is spontaneous and unthought-out; it is, as it were, natural. [...] In fact, it is the concrete link between representation and reflection" (82). In this link between representation and reflection, or thought and speech, is not Spanglish, simply put, a person's way of doing just this? Spanglish may come to represent so much more, when analyzed by society, but when a person is naturally expressing his or her self, he or she does not think about how it is being done. Yet the end product, Spanglish, again does represent more than mere communication. As Juan Pablo Vera and Jefferson Jaramillo point out, quoting Hunt and Bonnell, (1999): "La crisis de la representación consiste en una nueva concepción de lo social, que se desplaza de la posibilidad de explicar causalmente los hechos sociales hacia una concepción que considera que el lenguaje -en todas sus manifestaciones: escritas, orales, corporales, etc.- forma y transforma el conocimiento que configura nuestra concepción sobre la realidad" (Vera and Jaramillo, 248).

When thinking of how Spanglish shapes the identity and thus the reality of its speakers, we go back to Marcuse because he explains how one's native language is: "[i]nsistence on the philosophical elements in grammar, on the link between the grammatical, logical, and ontological "subject," points up the contents which are suppressed in the functional language, barred from expression and communication"
(77). Grammar seems to go beyond the formal grammar of a language, and can represent the individual's identity. The idea of " "la grammaire intériorisée " or an innate grammar that all people theoretically possess and which is " un phénomène humain d'ordre biogénétique et psycho-social » (a human phenomenon of the biogenetic and psycho-social order, Besse \& Porquier, 13-22, my own translation) comes into play here, a grammar that represents the human being beyond the spoken language, a representation of the person in his or her entirety.

Juan Pablo Vera Lugo and Jefferson Jaramillo Marín in their article "Teoría social, métodos cualitativos y etnografía: el problema de la representación y reflexividad en las ciencias sociales" say: "No es extraño entonces que en dicho marco emergiera una nueva gramática de lo social, interesada en cuestiones postnacionales, postestatales, en la relación global-local, en las problemáticas de género, en las historias locales, en las distintas manifestaciones de los movimientos sociales, en las nuevas sociabilidades y en los procesos de individuación" (247). If, as Marcuse states above, grammar is so important in the construction of identity, how can, as Anzaldúa pointed out, a speaker of Spanglish have a clear notion of whom he or she is? Perhaps, an even more important question is to ask if Spanglish plays a positive role in the life of a Spanglish speaker, providing him or her with an identity and a means of personal expression, or if it plays a negative role, placing the person in a reduced world where they can only really communicate with other speakers of Spanglish, thus limiting their possibilities for success in society. 
The "identity crisis" that Anzaldúa refers to is also expressed by Vera and Jaramillo who cite Hunt and Bonnell, (1999): "La crisis de la representación consiste en una nueva concepción de lo social, que se desplaza de la posibilidad de explicar causalmente los hechos sociales hacia una concepción que considera que el lenguaje - en todas sus manifestaciones: escritas, orales, corporales, etc.- forma y transforma el conocimiento que configura nuestra concepción sobre la realidad. Esta concepción da tránsito a la aparición de una nueva forma de nombrar el mundo y proporciona a la teoría social un nuevo cuerpo de conceptos y significados, una visión que 'sustituye' conceptos tradicionales como estructura social, clase social y comportamiento, por el estudio de lo simbólico, el significado, las prácticas culturales, el lenguaje, el poder y la dominación" (Vera and Jaramillo, 248). Here, Vera and Jaramillo speak of language in "all of its manifestations, written, spoken and corporal." Normally, Spanglish is not written, it is usually spoken, if it is not being used for commercial reasons. It may be written in a letter from one Spanglish speaker to another, or in a formal study of Spanglish.

Robert J. C. Young, in Postcolonialism: A very short introduction, says the following about translation and cultures, and how translating changes people:

[T]o translate a text from one language to another is to transform its material identity. With colonialism, the transformation of an indigenous culture into the subordinated culture of a colonial regime, or the superimposition of the colonial apparatus into which all aspects of the original culture have to be reconstructed, operate as processes of translational dematerialization. [...] As a practice, translation begins as a matter of intercultural communication, but it also always involves question of power relations, and forms of domination (Young, 139-140).

This search for identity expressed so often through the language is not only seen between Spanish and English, it can be seen any time since one or several cultures are dominating and suppressing other cultures. When talking about language and control, Walter Mignolo, cites Frantz Fanon in his book Black skin, White Masks (1967 [1952]) who says, "To speak means to be in a position to use a certain syntax, to grasp the morphology of this or that language, but it means above all to assume a culture, to support the weight of a civilization..." (Mignolo, 2009, 7). Mignolo also states in his article "Geopolitics of sensing and knowing: On (de)coloniality, border thinking, and epistemic disobedience" the following:

Languages that were not apt for rational thinking (either theological or secular) where considered languages that revealed the inferiority of the human beings speaking them. What could a person that was not born speaking one of the privileged languages and that was not educated in privileged institutions do? [...] That is, two of the choices are to accept the humiliation of being inferior to those who decided that you are inferior or to assimilate (Mignolo, 2013, 133-134).

Theodor Adorno and Max Horkheimer speak of the industry of culture in their article "The Culture Industry: 
Enlightenment as Mass Deception." When describing how culture is often spoken of in technological terms, they say the following:

A technological rationale is the rationale of domination itself. It is the coercive nature of a society alienated from itself [...] It has made the technology of the culture industry no more than the achievement of standardization and mass production, sacrificing whatever involved a distinction between the logic of the work and that of the social system [...] The need which might resist central control has already been suppressed by the control of the individual consciousness (1).

This description of culture shows us exactly what happens with Spanglish. The people who speak Spanglish are often alienated. Spanglish must be, according to those controlling society, standardized into the mass of "correct" Spanish or English, and the individual consciousness of a Spanglish speaker, as Anzaldúa pointed out, is controlled by society.

Douglas Kellner, in his article "The Frankfurt School and British Cultural Studies: The Missed Articulation" when speaking of the global postmodern era, economy and culture, quotes Stuart Hall who says that history, language and literature are the "three great supporting pillars of national identity and national culture" [... for] the global postmodern involves a pluralizing of culture, openings to the margins, to difference, to voices excluded from the narratives of Western culture" (8-9). If language is one of the great supporting pillars of national identity and national culture, does this not mean that
Spanglish is a "pillar of the national identity" of the people who speak it? Does Spanglish not "pluralize" the culture where it is spoken? If so, then the question becomes, does Spanglish offer openings to those who are marginalized or does it do exactly the opposite? Later, Kellner states that: "Crossing borders inevitably pushes one to the boundaries and borders of class, gender, race, sexuality, and the other constituents that differentiate individuals from each other and through which people construct their identities" (12). Speaking Spanglish implies the construction of the individual's identity and of the community's identity where it is spoken. Is this a conscientious decision made by the individual, or one that is imposed upon him or her? If social identity is in part situational, one can argue that it becomes a resource to deal with cultural difference, for good or bad. After all accommodation and rejection are two opposite possibilities in the performance of social identity as strategies for survival.

Another way that a person can at least partially construct his or her identity is through food. As language is something that all people inherently possess and develop and can be considered necessary in a person's life, food is something that all people do need, since without it they would die. In some circumstances, visualizing food items and practices could be dangerous as well, because they reveal cultural difference. Interestingly, when one combines food from different cultures to make a new dish, this is not considered to be negative or controversial, at least not for most people. There may be purists who disagree with mixing foods of different "nationalities," 
but new dishes are created precisely by doing this. As Vanessa Fonseca tells us in her article "Nuevo Latino: Rebranding Latin American Cuisine": "This tension between being oneself and fantasizing a metamorphosis into someone else through a consumption experience also exemplifies the identity question behind Nuevo Latino Cuisine. Nuevo Latino is [...] an experience where diners are invited to displace palates and imagination by daring to join an exotic carnival of flavors, ambiances and identities. Furthermore, this cannibalization of cultural differences is branded as a sophisticated, refined lifestyle" (109). In this example, food is more than food, it is an experience, but an expensive one, since not all Latinos are going to be able to afford this kind of food that is branded as "sophisticated" and "refined." This is therefore not an identity that would be necessarily open to all classes of people.

However, food also constructs identity among the popular classes. Anzaldúa talks about food and sensory perceptions that helped construct her identity:

For me food and certain smells are tied to my identity, to my homeland. Woodsmoke curling up to an immense blue sky; woodsmoke perfuming my grandmother's clothes, her skin. The stench of cow manure and the yellow patches on the ground. [...] Homemade white cheese sizzling in a pan, melting inside a folded tortilla. [...] Even now and 3,000 miles away, I can see my mother spicing the ground beef, pork and venison with chile. My mouth salivates at the thought of the hot steaming tamales I would be eating if I were home (83).
In analyzing what is happening here with Latin American Cuisine, a direct comparison can be made with Spanglish. Spanglish is a mix of Spanish and English. When foods from different cultures and countries are combined, new culinary creations are created, just as new linguistic creations are made with Spanglish. Combing foods gives one a new dish. Combing Spanish and English gives one new words, for example, a new verb, "cookiar" (to cook) or a new noun, "carpeta" (carpet) (Anzaldúa, 79). And the creators of Nuevo Latino are aware of this fact as can be seen in this food review: "Cibucan is for the adventurous diner looking to experience the unusual (www.cibucan.com). Brench? Frazilian? There's no precise definition for the creative cuisine chefowner E. Michael Reidt is concocting at Bomboa, a new French-Brazilian eatery in the Back Bay-South End area. (http://www.bomboa.com/reviews/herald.html)." The play on words with Brench and Frazilian is a combination of words to create new words, just as it happens with Spanglish.

And these puns and combinations of words and flavors are all marketing. In fact, Spanglish is highly marketable, and a glance at the billboards in and around Latin American cities will prove this. Even though the use of Spanglish can be controversial, it is also very popular. Its real popularity is seen when one changes from studying Spanglish from a scholarly or linguistic perspective to a marketing perspective. Like sex, Spanglish sells. A quick search on the web for Spanglish gives many websites, most of which are trying to sell something. If one "googles" a little farther, for example "Marketing Spanglish," countless websites explaining 
how to market Spanglish are found. There are also magazines in Spanglish, and websites talking about Spanglish related topics. For example on Forbes' web site we find the following article: "Advertisers to Latinos: "We Love it When You Speak Spanglish." This article talks about Fox, Facebook, Twitter, and radio which all target Spanish speakers and Spanglish speakers. This brings up and interesting point: Spanglish is a highly marketable commodity.

As the Nuevo Latino Cuisine, Spanglish is marketed. However, there are two types of Spanglish: the one that is being marketed and exploited, and the one seen in Anzaldúa's case. The speakers of Spanglish do not sell their language; they use it for communicative purposes. But Spanglish can be taken and marketed by others. Thus, the people who create and speak it receive no money, as the unknown and unseen Latino who helps the owner create his artistic culinary "masterpieces" receives no money, beyond his salary, and no real glory or fame. Thus, the Latino continues to be exploited, here by his or her own people, if the restaurant is owned by a Latino. Anzaldúa states that Spanglish represents a certain liberation or at least construction of identity for the Latino people: "Chicano Spanish sprang out of the Chicano's need to identify ourselves as a distinct people. We needed a language with which we could communicate amongst ourselves, a secret language" (77).

But if a person only speaks Spanglish, he or she will be marginalized in the job market, for one must speak English in order to be "successful." In the same way, New Latino Cuisine is an expression of culinary freedom and expression, but also a form of oppression:

[S]ome chefs are co-owners or owners of their restaurants, making the emancipatory and evangelical mission of Nuevo Latino a plausible task, at least for the chefs. Therefore, if there is any agency in Nuevo Latino Cuisine, it is not in terms of class mobilization, but rather as individual agency. One can contrast the glory and fame achieved by Douglas Rodríguez with the anonymous kitchen staff, who inspired him and perhaps continue to help him with new ideas while receiving minimum wages as cooks (Fonseca, 120).

Another point of comparison between Spanglish and Latin American cuisine is seen in the idea that some people who criticize Spanglish think that Spanglish "bastardizes standard English" (Stavans 2008, preface). Gloria Anzaldúa, states that critics of Spanglish call it "a bastard language" (80). In the same way, New Latino Cuisine will not be accepted if it is not prepared correctly as Fonseca points out quoting Gina La Vecchia: "But as the public becomes more educated, they will be less forgiving of a place that bastardizes the cuisine" (Fonseca, 111). This idea of the illegitimacy of English (and Spanish) and of "genuine" Latino cuisine is also a power game. If something is not what society wants, it is illegitimatized and referred to as a "bastard." True, it can be said that Latin-American cooking traditions were associated to ancestral food, exotic ingredients and delicacies that were "aestheticized" through high culinary techniques or ingredients, and have become in essence art forms and pure 
simulacrum. They achieve their legitimization by being transformed from a traditional dish into a more cosmopolitan, sophisticated food item. Spanglish, on the other hand, as a "modern language," is bastardized by variants that are considered as "barbarian" ways of speaking and writing. Here, otherness is assessed not as exotic and fine, but as illiterate in both Spanish and English. Moreover, illiteracy can also be associated to class perception. It is one speaking Spanglish at the border of two legitimate modern languages. His or her identity is at the hyphen, always in crisis. However, when Spanglish is used in advertising, it becomes in a way as legitimate as Latin American cuisine. It too, can be considered sophisticated and cosmopolitan, and achieves its legitimization, or at least an attempted legitimization through the fact that it is used on television; it is used in advertising and other media. In sum, Spanglish becomes something trendy in society, and advertising takes advantage of it. Again, as seen above, "Advertisers to Latinos: We Love it When You Speak Spanglish."

What is interesting here is that for the most part New Latino cuisine is accepted, unless as seen above it is "bastardized." Spanglish, as we have seen, is not accepted by all people. Why is it normally positive and good to mix Latino foods with other foods from other countries, but not all right to mix Spanish and English? Is not the natural process of two languages mixing more "natural" than mixing different foods from different nationalities? Perhaps the controversy that is found in Spanglish that is not seen in Nuevo Latino Cuisine comes from the fact that Spanglish imposes itself upon society and is not searched out by everyone, while food, especially in a restaurant situation, where one is going out to have a good time, only brings pleasure or status and cosmopolitism. Food is also advertised, it needs to attract buyers and customers, while speakers of Spanglish do not sell their own language; it is not a commodity, it is a part of their identity. However, Spanglish itself can be used to sell other commodities or products, and Spanglish advertisers could argue that it the best way to reach second and third generation Latinos.

Spanglish and advertising are not simply a combination of Spanish and English to make a commercial or advertisement, other factors are involved in the process. For example, who is being targeted by the advertising agencies when they create their advertisements and commercials: only speakers of Spanglish or are they also looking to sell to English or Spanish speakers? Why combine Spanish and English if Spanish and Spanglish speakers and English speakers are surviving and buying things without Spanglish ads? The obvious answer is to sell more. Mixing languages, if done correctly, is a great advertising strategy. One reason is that a foreign word will capture the attention of the person reading the advertisement. Teresa Gómez Cerdeño maintains that when English is put into Spanish advertisements, for example, the advertiser is trying to give a certain status to the product, creating an effect on the would-be buyer. The theory is that the foreign word, in this case English, is "unusual information" and will be remembered by the reader (10). This phenomenon is known as foreign branding and its effects are seen on product perception and people's attitudes. 
In other words, Spanglish in advertising works and not just on a conscious level, such as seeing a funny word made up of Spanish and English, but on a much deeper level. Karla Michelle Esquivel explains:

In fact, a strong argument for how "Spanglish" will affect the industry lies in theory of communication [...] the Sapir-Whorf hypothesis of linguistic relativity provides an understanding of how language is, "a kind of schema through which the world is understood and interpreted" (Koslow, 1994, p. 123). For this reason, again, language in fact has a deeper connection with a consumer and the form used can trigger an emotion or reaction within the individual (17).

Esquivel goes on to point out that if advertising agencies are using Spanglish in their advertisements it is again, because it works and it sells. The advertising agencies are not going to spend money on campaigns that do not make money: "The fact of the matter is that language does make a difference. One would not use a foreign language to advertise to a general market unless there was proof that that would be a successful strategy and produce an understanding within the individual" (8).

Taylor agrees that Spanglish works in advertising: "Advertisers have discovered when advertising to MexicanAmericans in Texas, Spanglish is marketing gold (Clark, 2007). Spanglish is effective because not only do Hispanics understand the language but they also appreciate it (Clark, 2007). In fact, Hispanics often use Spanglish as a bonding mechanism (Nueliep, 2003)." Taylor also says that Spanglish works in advertising because: "Often times words in one language have deep or symbolic meanings that do not translate exactly into any others. By using the original language of a word, the full impact of its meaning will transfer into an ad" (Luna \& Peracchio, 2002) (Taylor, 19).

Spanglish, as has been pointed out by Stavans, Andzaldúa and others, is often criticized, especially by scholars, but as far as marketing goes, the advertising industry loves it. It is used in headlines and texts in magazines, probably because if Spanglish speakers are attracted by Spanglish advertisements enough to buy the product being offered, it is because it speaks to their identity. As Vivian Rojas and Juan Piñón assert: "We have seen that language is central to the cultural hybridity process (mestizaje) [...]. From this perspective, the bilingual-bicultural networks appear to display a multicultural project that, in spite of its commercial nature, still allows some spaces of agency to specific actors represented in the networks" (4). They continue, saying that: "Spanglish, which is highly controversial in educational settings, is being celebrated on the Latino bilingual networks and, to an extent, in Latino trade magazines and media publications. Writers capture the new bilingual-bicultural context in their headlines and texts and with phrases such as 'playful Spanish-English fusion,' 'bilingual reality,' 'bicultural can-do' and 'Planet Spanglish"' (5).

Katherine Hagan also supports the idea that Latinos relate to Spanglish in advertising saying: "Qualitative analysis serves to assess the motivations, rules, and ramifications of meshing Spanish and English in the media. 
Such analysis reveals that the function of advertising language is often more symbolic than referential. Close readings of the ad also serve as an additional account of linguistic correlates of 'Spanglish' in the hybrid communication between advertiser and consumer" (1). In addition, Patrica Vega Jiménez states that the consumer also uses consumer goods to create and to express his or her identity: "El consumidor usa este significado [el de bienes de consumo] con propósitos enteramente culturales. [... para] cultivar ideales, crear y mantener las formas de vida, nociones para la construcción del sí mismo y crear (y sobrevivir) al cambio social. De modo que el consumo se reviste de un carácter profundamente cultural" (Vega, 62).

Even though Latinos relate to Spanglish advertising, this does not mean that they will naively and happily swallow any Spanglish add that is put before them. Just as Latino voters in the United States did not all run to the polls and vote for George Bush just because he spoke a few sentences in Spanish during his campaign, neither will they appreciate any add that happens to contain Spanglish. Latinos are sensitive about their language. As Gloria Anzaldúa said: "If you want to really hurt me, talk badly about my language. Ethnic identity is twin skin to linguistic identity - I am my language. Until I can take pride in my language, I cannot take pride in myself" (81). Latinos do not appreciate it when their language is made fun of or badly represented:

Hispanics will take very strong note on what exactly the brand is doing and if they can relate to the product. At times, if a brand in some way offends the Hispanic culture or simply what one individual finds offensive, then the feelings towards that brand change. This could be said for any consumer group or individual, but in the case of Hispanics they are very proud of their heritage and do not take insult or offense very lightly (Esquivel, 8-9).

If Spanglish advertising is done correctly, and the Latino community accepts the ads that are created, this can also be a way of legitimizing Spanglish. After all, if Spanglish is on television and on the radio, in magazines and on billboards, then it becomes a tangible reality that can be seen. Rojas and Pinón affirm: "In many ways, the rise of the bilingual networks seems to follow these complex new hybrid cultural processes. On one hand they 'relocalize' young U.S.-born Latinos within the industry's new category of 'bilingual audience' as a market to be exploited and, on the other hand, they create and use a 'new television lexicon' on the basis of language hybridity - Spanglish - that reflects current cultural dynamics and tensions among the diverse geographic, national and racial Latino groups and their identities. [...] one in which language and cultural diversity play central roles" (4).

In the twenty first century where diversity and dynamism are undeniable components, the use of languages and their mixtures and combinations is not rare. Therefore, the use of Spanglish in advertising is reinforcing these twenty first century traits. Dynamism and diversity are part of it, and in the manipulative and commercial process of making profits, feelings of identification, compensation, importance as 
well as desires for exoticism and prestige emerge. The use of Spanglish in advertising contributes to processes of individual and collective identities, sometimes imaginary, sometimes forgotten or hidden, sometimes borrowed and sometimes fake. The profit of the individual who faces Spanglish in advertising is not buying or selling a product but seeing and understanding how language can control and be controlled, and how feelings and needs can be used in this linguistic mixture and marketing transformation.

\section{Bibliography}

Adorno, T., \& Horkheimer, M. (2007). The culture industry: Enlightenment as mass deception. Stardom and Celebrity: A Reader. London and Thousand Oaks, CA: SAGE Publications, 34-43.

Advertisers to Latinos: "We Love it When You Speak Spanglish" www. forbes.com/...es/giovannirodriguez/2012/01/30/...

Anzaldúa, G. (2012). Borderlands: la Frontera. The New Mestiza, San Francisco : Aunt Lute Books.

Ardila, A. (2005). Spanglish: an anglicized Spanish dialect. Hispanic Journal of Behavioral Sciences, $27(1), 60-81$.

Barthes, R. (1972). Mythologies. 1957. Trans. Annette Lavers. New York: Hill and Wang, 302-06.

Besse, H., \& Porquier, R. (1991). Grammaires et didactique des langues. Paris : Hatier.

Bulletin of the Business Historical Society, Vol. 3, No. 4 (Jun., 1929), pp. 11-13. Published by: The President and Fellows of Harvard College.
Cárdenas Torres, M. (2010, June). Migración, ciudadanía y articulación en red. El caso de la SB 1070. (Axe I, Symposium 2). In Independencias-Dependencias-Interdependencias, VI Congreso CEISAL 2010.

Esquivel, K. M. (2012). Code switching: how Latinos are changing advertising and the Spanish language. (Master's thesis). Retrieved from repositories.lib.utexas.edu

Fairclough, M. (2003). El (denominado) Spanglish en Estados Unidos: polémicas y realidades. Revista Internacional de Lingüistica Iberoamericana, Vol. 1, No. 2 (2), El español de los EE.UU., pp. 185-204.

Fonseca, V. (2005). Nuevo Latino: Rebranding Latin American Cuisine. Consumption, Markets and Culture, 8(2), 95-130.

Foucault, M. (2002). The order of things: An Archaeology of the human sciences. Psychology Press.

Gómez Cerdeño, T. (2010). The use of foreign words as a persuasive tool in Marketing discourse: the cultural stereotype of global English in Spanish print advertising (Master's thesis). Retrieved from eprints.ucm.es

Hall, S. (1985). Signification, representation, ideology: Althusser and the post-structuralist debates. Critical Studies in Media Communication, 2(2), 91-114.

Harvey, D. (1990). The Condition of Postmodernity. An Enquiry into the Origins of Cultural Change. London: Blackwell.

Kellner, D. (2002). The Frankfurt School and British cultural studies: The missed articulation. Rethinking the Frankfurt School: Alternative 
Legacies of Cultural Critique, 31-58. Retrieved from books.google.com

Lipski, J. (2004). Is "Spanglish" the third language of the South?: truth and fantasy about US Spanish. In 3rd Language Variation in the South (LAVIS III) conference, Tuscaloosa, AL. Lyotard, J. F. (1984). The postmodern condition: A report on knowledge (Vol. 10). Minnesota : University of Minnesota Press.

Marcuse, H. (2013). One-dimensional man: Studies in the ideology of advanced industrial society. New York: Routledge.

Martínez Luna, S. (2010). La crítica de la cultura después de la cultura. Estudios visuales. Retóricas de la resistencia, 7, enero.

Mignolo, W. (2013). Geopolitics of sensing and knowing: On (de) coloniality, border thinking, and epistemic disobedience. Confero: Essays on Education, Philosophy and Politics, 1(1), 129-150.

Mignolo, W. D. (2009). Epistemic disobedience, independent thought and decolonial freedom. Theory, Culture \& Society, 26(7-8), 159-181.

Norris, V. P. (1980). Advertising history-according to the textbooks. Journal of Advertising, 9 (3), 3-11.

Parra, V. (2011). Advertising Trends for the Hispanic Market. Retrieved from digitalcommons.calpoly.edu

Rojas, V., \& Piñón, J. (2014). Spanish, English or Spanglish? Media strategies and corporate struggles to reach the second and later generations of Latinos. International Journal of Hispanic Media, 7.

Schmidt, B. E. (2003). Teorías culturales posmodernas de Latinoamérica (y su importancia para la etnología). Indiana, 19 (20).
Stavans, I. (2012). La Nueva Hispanidad. Cuadernos de Pensamiento Político, No. 35, pp. 147-154.

Stavans, I. (ed.) (2008). Spanglish. Westport: Greenwood Publishing Group, Inc.

Stavans, I. (2003). Spanglish: The making of a new American language. New York: Rayo.

Stavans, I. (2000). Tickling the Tongue. World Literature Today, 74 (3), pp. 555-558

Taylor, N. (2009). Rio Grande Hispanic consumers' perceptions of Spanglish dialogue use in print and television advertising. Texas: The University of Texas-Pan American.

Tungate, M. (2007). Adland: a global history of advertising. Kogan Page Publishers.

Vega Jiménez, P. (2008). Estrategias publicitarias en Costa Rica (19001930). Pensar la Publicidad. Revista Internacional de Investigaciones Publicitarias, 2(1), 45-78.

Vera Lugo, J. P., \& Jaramillo Marín, J. (2007). Teoría social, métodos cualitativos y etnografía: el problema de la representación y reflexividad en las ciencias sociales. Universitas Humanística, 64(64).

Vidal Jiménez, R. (1999). La historia y la postmodernidad. Espacio Tiempo y Forma. Serie V, Historia Contemporánea (12).

Young, R. J. (2003). Postcolonialism: A very short introduction. Oxford: Oxford University Press.

Zuñiga Tristán, V. (1976). El anglicismo en el habla costarricense. San José: Editorial Costa Rica. 